\title{
LA FLAUTA DE PAN DEL SACERDOTE GUERRERO DE SIPAN EN (DE) LA ALTA JERARQUIA MOCHICA
}

\author{
AVANCES DE INVESTIGACIÓN ${ }^{1}$ \\ CARLOS D. SÁNCHEZ HUARINGA \\ UniVERSIDAD NACIONAL MAYOR DE SAN MARCoS \\ karlos_202@hotmail.com
}

\section{RESUMEN}

El año 2007 el arqueólogo Luis Chero Zurita descubre la tumba número 14 del llamado "Sacerdote Guerrero" de Sipán perteneciente a la élite Mochica, y en su ajuar funerario se encuentra una veintena de artefactos sonoros (pututos y cornetas) e instrumentos musicales (flautas de pan o "antaras"). Desde una perspectiva de propuesta de investigación, desarrollamos en el presente artículo una exploración de diversos aspectos arqueo musicológicos de esta flauta de pan y su relación con el personaje mencionado, generando interrogantes y pistas para una necesaria futura investigación.

PalabRas Clave: Música, flautas de pan, antaras, zampoñas, Moche, Sacerdote Guerrero, Sipán.

\begin{abstract}
In 2007, the archaeologist Luis Chero Zurita discovers the tomb number 14 of the "Warrior Priest" of Sipan Moche belonging to the elite, and their grave goods is twenty sound artifacts (pututos and horns) and musical instruments (flutes bread or "antaras"). From the perspective of research proposal, developed in this article an exploration of various tonnage musicological aspects of the panpipes and its relationship with the character mentioned, raising questions and clues for future research needed.
\end{abstract}

KeYwords: Music, pan flutes, panpipes, Moche, Warrior Priest, Sipan.

1. Avance escrito entre los años 2012 y 2013 en momentos que "descubrimos" estas flautas de pan en el museo de Huaca Rajada de Sipán en Lambayeque. Fue reescrito, corregido sin eliminar su sentido original, para la presente publicación. 


\section{INTRODUCCIÓN}

El año 2012 realizamos una visita de exploración a los diversos museos de los departamentos de La Libertad y Lambayeque con el objetivo de encontrar nuevos descubrimientos sobre las flautas de pan del tiempo prehispánico, más aún en sociedades norteñas como Mochica y Chimú que siempre nos habían llamado la atención por la ausencia de restos físicos de flautas de pan cuando por el contrario sí observamos muchos restos iconográficos y cerámicos que evidencian un posible uso furtivo de este aerófono andino. Hasta entonces conocíamos solo tres flautas de pan de posible origen Mochica: 1) Posible flauta de Pan de cañas que se encuentra en el museo de Alemania, 2) Flauta de pan de cerámica que se encuentra en el Museo Nacional de Arqueología e Historia del Perú y 3) Flauta de pan de cerámica ubicado en el museo Cassinelli de Trujillo, La Libertad (Sánchez 2013: 70). Ciertamente la inexistencia de mayores restos físicos de este tipo de instrumentos musicales, ha sido una de las razones que no ha permitido lograr un mayor conocimiento sobre ellos en la sociedad Mochica.

De esta manera encontramos que en el museo de sitio "Huaca Rajada" de Sipán se exhibían los restos de unas "antaras" halladas en las excavaciones de una importantísima tumba signada con el número 14 y que le pertenecería al "Sacerdote Guerrero de Sipan". Se trataba posiblemente del mismo personaje que se encuentra "retratado" en la famosa imagen llamada la "Presentación" o el "Sacrificio" (Imagen 1), así nos sugirieron los especialistas del Museo con quienes conversamos (Walter Alva y Luis Chero Zurita) y fue citado entonces en mi libro publicado el año 2013: "sabemos que uno de los mayores jefes y autoridades que acompañaba al señor de Sipán gustaba también de este instrumento pues fue hallado entre los bienes que acompañaron su entierro." (Sánchez 2013: 70).

Por lo tanto este aerófono prehispánico encontrado en la cámara funeraria de un personaje de gran importancia nos llamó profundamente la atención y en el momento nos generaron varias interrogantes: ¿Este instrumento pertenecía al personaje de la élite Mochica o habría sido una ofrenda? ¿Cuáles eran sus características morfológicas y musicológicas? ¿Se trataba de una flauta de pan dual o individual? ¿Por qué este instrumento musical en la tumba de un personaje considerado sacerdote y guerrero? ¿Por qué aparentaba simpleza en su construcción tratándose de un personaje de alta jerarquía?

Se requería por supuesto una mayor y profunda investigación e iniciamos por ello los trámites para obtener el permiso y poder revisar a profundidad estos instrumentos y principalmente tener acceso a los registros del desentierro, puesto que en el momento los especialistas no podían resolvernos algunas dudas comprensiblemente por ser muy específicas, por ejemplo ¿Cómo habían sido halladas los tubos, sueltos, juntos, con amarres, etc.? Sin embargo, ya teníamos algunas ideas de lo que estas flautas de pan Moches encerraban y aquí alcanzamos lo hallado hasta entonces.

\section{LA IMAGEN DEL "SACRIFICIO" O DE LA “PRESENTACIÓN"}

Una de las imágenes más famosas y representativas que nos ha dejado la sociedad Mochica sin duda es el "Tema de la Presentación" o del "Sacrificio" (Imagen 1). Esta imagen fue descubierta en una botella gollete de asa estribo hecho de arcilla perteneciente a la época del Auge Mochica (1 d.C. - 800 d.C.) y fue encontrado en la costa norte en el Valle de Chicama en el sitio de Facalá, la pieza pertenece a la colección Larco (ML010847)2. La imagen fue llamada del "Sacrificio" (Hocquenghem 1987)1 debido a que esta culmina con la muerte ritual de los prisioneros, y es también conocida como

2. El motivo de la imagen es una escena de sacrificio o presentación. La manera cómo las imágenes han sido representadas, la ubicación en el cuerpo esférico de la pieza, las oposiciones simbólicas que se pueden leer en ella, hacen de esta pieza una verdadera expresión de la cosmovisión de la sociedad Mocahica. En: http://www. seolarco.org/catalogo/ficha.php?id=11933 


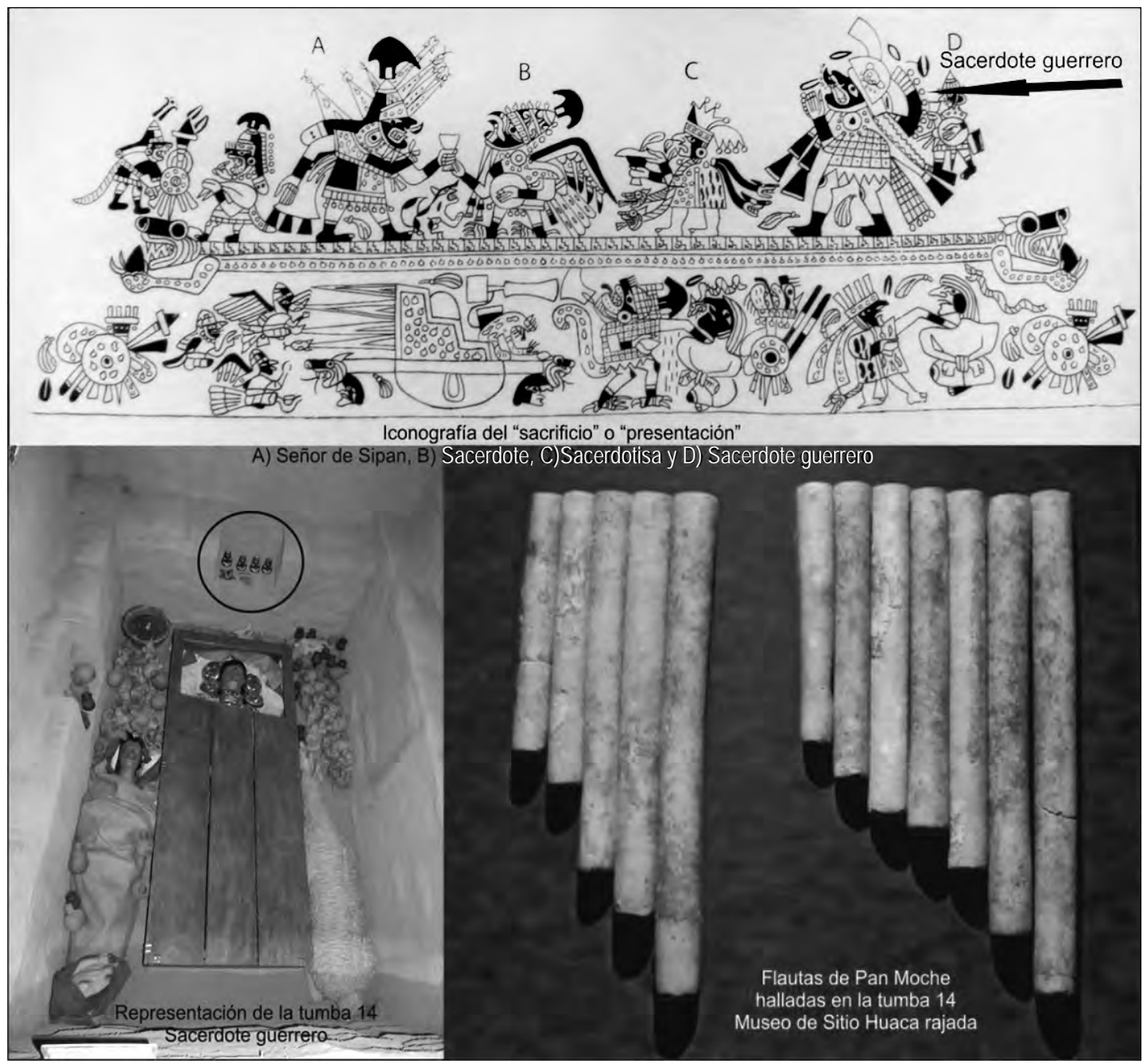

Podemos apreciar en este juego de imágenes (Sánchez: 2013) los tres elementos que dan vida al presente artículo: 1) La escena de la "Presentación" o del "Sacrificio". 2) La tumba 14, del "Sacerdote Guerrero" y 3) La flauta de pan (o "antara") hallada en dicha tumba.

de la "Presentación" (Donnan 1975) debido que la sangre es presentada en copas ceremoniales a una importantísima divinidad. Se trata sin duda de la representación de una importante escena ritual donde elementos cosmogónicos (ritualidad, religiosidad, política, poder, etc.) de la sociedad Mochica se conjugan simbólicamente.

Los arqueólogos han determinado que la imagen retrata explícitamente una reunión de personajes de la más alta jerarquía Mochica:

Como observamos en la parte superior de la escena aparecen estos cuatro personajes que por su indumentaria tan espectacular y por sus actitudes representarían a integrantes de la élite ya que portan elementos funerarios, de rango, mando y culto bastante característicos. Estos cuatro personajes son distintos, dos de ellos, situados en los extremos, son más grandes, están mejor ata- 
viados y parecieran representar los de mayor rango. Los otros dos personajes, situados entre los anteriores, parecieran ser de rango inferior, siendo una de ellas mujer, y ambos parecen dirigirse al personaje ubicado en el extremo izquierdo. ${ }^{3}$

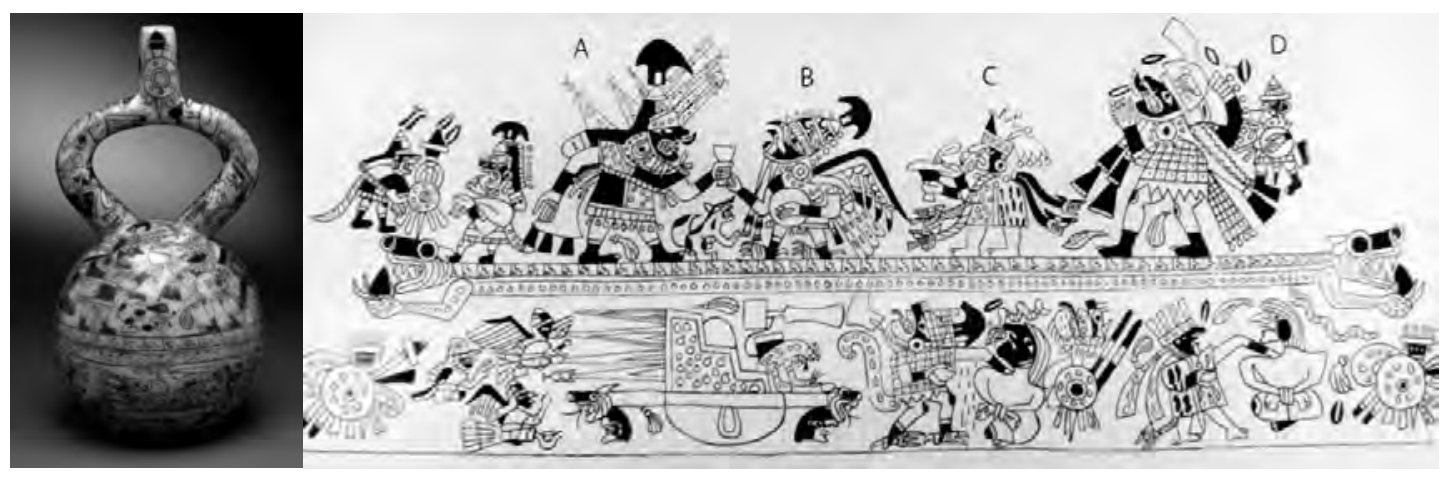

Imagen 1a) Botella arqueológica de asa estribo (colección Larco) perteneciente a la época del Auge Mochica donde observamos la escena del "Sacrificio" o de la "Presentación". Imagen 1b) Iconografía donde se observa a la alta jerarquía Mochica en un gran tinkuy ("encuentro") realizando un importante ritual donde la sangre y la muerte le dan sentido a una parte importante de la cosmovisión Mochica. Estos personajes de la élite Mochica existieron realmente y sus tumbas fueron halladas en el transcurso de estas últimas décadas.

Descripción de la escena:

En la parte inferior se puede observar la realización del sacrificio. Dos personajes desnudos con las manos atadas son degollados por dos seres antropomorfos y zoomorfos, quienes reciben la sangre en cuencos. Esta será la sangre a ser ofrecida a los dioses del mundo de arriba. Pero estos dos dioses no están representados en el mismo lado de la pieza. A un lado aparece sólo el Dios Radiante, con su característico casco guerrero con un tumi en la parte superior. Se le acerca el águila, que es el animal diurno que más se puede acercar al sol, y le entrega la copa con la ofrenda de sangre. En el lado opuesto de la pieza está el Dios Nocturno, que rige sobre el mundo oscuro y húmedo, las estrellas y la lluvia. Lleva su característico tocado de media luna con penachos, que a veces es reemplazado por un tocado en forma de pulpo. A él también hay que complacerlo, entregándole la sangre del sacrificio. Si vemos el lado de la pieza que se encuentra bajo el asa, veremos a una personaje femenino, la diosa Luna. Ella lleva trenzas que terminan en cabezas de serpientes. Desde el mundo oscuro, avanza hacia el mundo del día. Ella lleva la copa hacia el dios Radiante, dios solar. En este mismo lado de la pieza, en la parte inferior, se encuentra la acción del sacrificio. Este sacrificio debe ser realizado para propiciar el encuentro de las fuerzas opuestas y complementarias tan necesarias para permitir la vida: la luz y el calor del sol, y la lluvia. En el otro lado de la pieza, bajo el asa también, aparecen las dos cabezas de la serpiente bicéfala. La serpiente es símbolo de conexión entre los mundos. Sus cabezas están confrontadas y a la vez se encuentran, ofreciéndose ambas un fruto del sacrificio. El ritual del sacrificio, que se inició como una confrontación, termina en encuentro. ${ }^{4}$

Se trata de una reunión de la más alta jerarquía religiosa, político y militar Mochica donde cada uno tiene y cumple un rol y función diferente e importante. Fueron designados entonces como los personajes A, B, C y D (imagen 1b). Los arqueólogos aseguran que el personaje A sería el conocido Se-

3. http://arriero.galeon.com/index.html

4. http://www.museolarco.org/catalogo/ficha.php?id=11933 
ñor de Sipán, que el Sacerdote de Sipán se asemejaría al Personaje B, que la Sacerdotisa de Moro tiene grandes coincidencias con el Personaje C, y el personaje D sería justamente el Sacerdote Guerrero al que nos estamos refiriendo. ${ }^{5}$

\section{LA TUMBA 14, EL “SACERDOTE GUERRERo"}

Cuando morían los líderes de la sociedad Mochica que tenían poder político y religioso a la vez, la sociedad en su conjunto tenía que asegurar que cruzaran exitosamente de este mundo al mundo de los muertos, y que realizaran un buen viaje hacia su destino final, más cerca de los dioses. En ese viaje los líderes se transformarían en los ancestros de su sociedad, a la que cuidarían y por la que velarían desde una posición preferencial. Por ello el cuerpo del ancestro debía ser preparado y vestido con adornos y emblemas que darían cuenta de su posición social, funciones ceremoniales y pertenencia a algún linaje divino. Así, los arqueólogos han desenterrado a líderes Mochica que se fueron al "mundo de los muertos" vestidos de dioses.

Afines del año 2000 y a cargo del arqueólogo Luis Chero Zurita, se descubre los indicios de la tumba 14 y luego del 2007 se desentierra completamente. El ajuar funerario indicaba claramente que el personaje enterrado pomposamente, pertenecía a la élite de la sociedad Mochica. Se trataba sin duda (debido a la fuerte presencia del búho, animal que simbolizaría este rol), de un "sacerdote"; pero también de un "guerrero" y por el estudio comparativo, se llegaría a la conclusión que se trataría del "personaje D" de la famosa imagen mochica del tema del "Sacrificio" o la "Presentación". Luis Chero Zurita sostuvo entonces que el personaje "D faltante", había sido encontrado. ${ }^{7}$ Pero además, debido a los numerosos artefactos sonoros (conus y trompetas) e instrumentos musicales (flauta de pan) hallados con él, se le consideró "con labores de músico". Así estamos entonces ante el hallazgo de un personaje de la élite Mochica, guerrero, sacerdote y además un posible músico.

Dentro del ajuar funerario de este personaje de gran importancia y de la élite Mochica, se encontró una gran cantidad de artefactos sonoros: 10 "pututos" de cerámica (conus), 9 trompetas de cerámicas y una flauta de pan (o "antara", denominación arbitraria que usan los arqueólogos para todas las flautas de pan prehispánicas, también en este caso), todo ello lo relacionó inmediatamente con la música.

La réplica de la tumba 14 del "Sacerdote Guerrero" se encuentra en el museo de sitio de "Huaca Rajada" de Sipán (Lambayeque) y en las imágenes siguiente, podemos observar los detalles del ajuar funerario, principalmente la ubicación de la o de las "antaras" (en la cabecera del personaje) y que para el caso de la réplica, se ha utilizado una "zampoña" pequeña que actualmente se puede adquirir en cualquier mercado artesanal (imagen 2). De acuerdo a las premisas arqueológicas, en un entierro de esta naturaleza, acompaña al personaje todos los implementos que en vida fueron de su uso, además de las ofrendas.

5. Sin embargo, hay quienes sostienen que no hay una total certeza de que la tumba 14 pertenecería al personaje D de la "presentación”, pues podría ser también la Señora de Cao o el Señor de Úcupe. Revisar: http://arriero.galeon.com

6. http://www.museolarco.org/catalogo/ficha.php?id=11933

7. Se trata de un "hombre-búho" de carácter sacerdotal, pero luce armado con porra, estólica y escudo, las armas clásicas de los guerreros moches. Búhos y lechuzas abundan en el mundo, pero en los alrededores de Sipán y en casi todo el norte peruano, justo en el área de influencia de los moches, mantienen una relación especial con los agricultores. A diferencia de otras aves rapaces, el búho es un cazador nocturno, el que acaba con las sabandijas y siempre vinculado a la muerte y a la oscuridad. El búho era el señor de las tinieblas en una época -la de los moches- en que la noche se llenaba de peligros y amenazas para los hombres. En: http://huacarajadauss.galeon. com/cont.html 


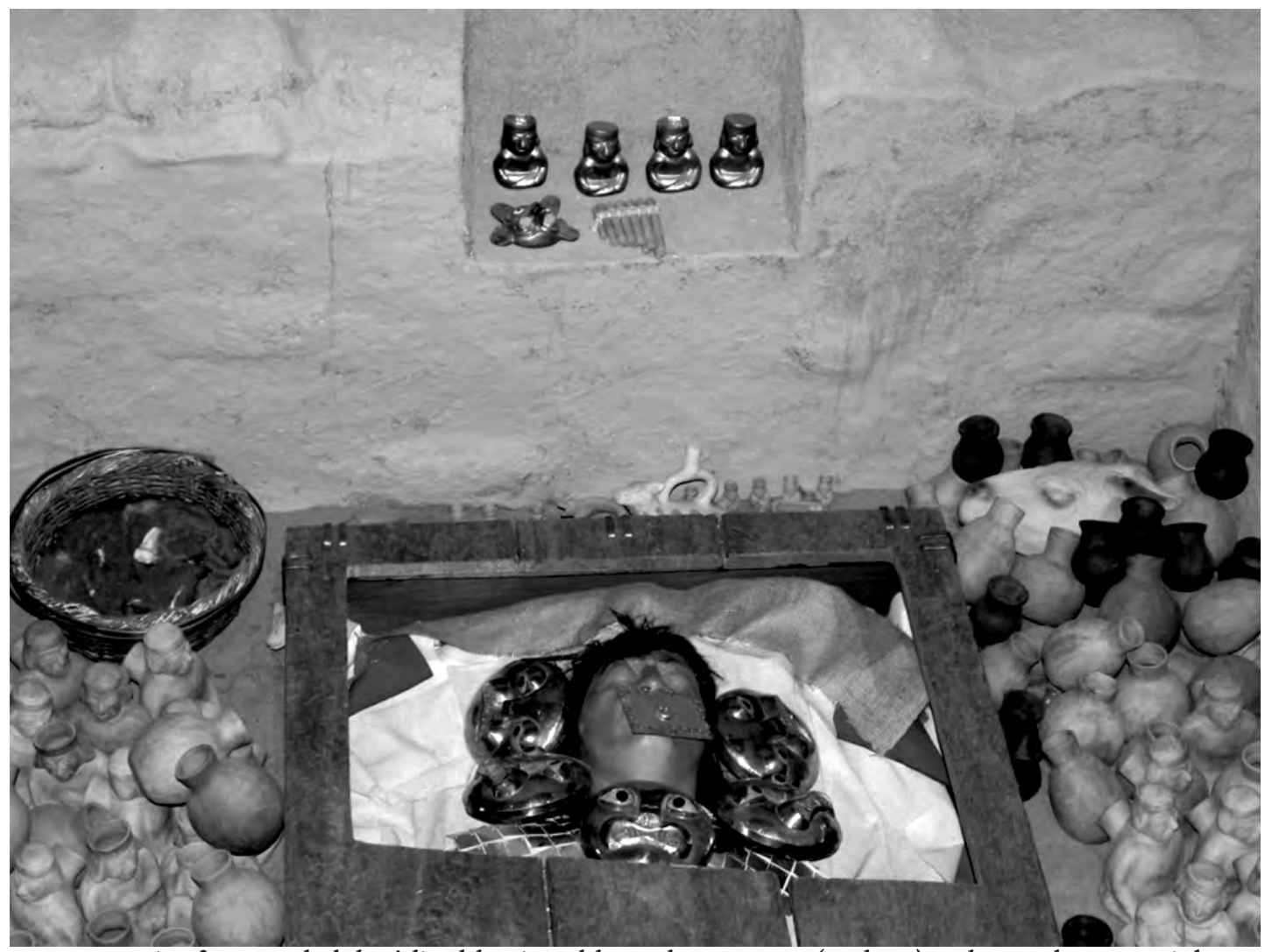

Imagen 2.- Vista fragmentada de la réplica del entierro del Sacerdote - Guerrero (tumba 14) en el museo de Huaca Rajada en Sipán (Lambayeque, Perú). Claramente podemos observar la presencia de una flauta de pan, posiblemente de su pertenencia.

\section{LA TUMBa 14 Y el PERSONAJE “D” DE la “PRESEnTACióN"}

Los arqueólogos aseguran que los personajes que fueron representados en la imagen de la "presentación" o "sacrificio", no pertenecen al imaginario o al espacio divino, sino fueron sacerdotes y sacerdotisas, autoridades políticas, militares y religiosas que existieron y cuyas tumbas han sido encontrados a lo largo de estas últimas décadas. Luis Chero Zurita afirma sobre la tumba 14 que "por el ataúd, por la corona, por los dos vestidos de plata en forma de triángulos consideramos que se trata del personaje D de la "Presentación" o "Ceremonia del Sacrificio" (Museo Huaca Rajada de Sipan, 2012). ${ }^{8}$

En el museo de sitio de Huaca Rajada se describe la escena de la "Presentación" así: El "Ser Radiante" (A), personaje principal, porta ornamentos y emblemas que corresponden fielmente a los encontrados en la Tumba del Señor de Sipán que en su tiempo fue la máxima autoridad política, militar y religiosa de la región. Los otros personajes que se dirigen al principal, fueron después identificados como el sacerdote (B) figurado como un "hombre búho", cuya tumba también fue recuperada en Sipán. Posteriormente se encontró en San José de Moro, la tumba de una mujer que por sus ornamentos correspondía a la sacerdotisa, personaje (C). Las excavaciones del año 2007, lograron recuperar e identificar la tumba del personaje (D) que faltaba para completar la alta jerarquía de los Mochicas en la región de Lambayeque, a este se le ha llamado "Sacerdote Guerrero" puesto que las 
vestimentas y ornamentos de su ajuar funerario indicaban funciones militares y religiosas. Este personaje (D) aparece además representado en varios temas de la iconografía Mochica, bien recibiendo la copa del sacrificio de manos de la sacerdotisa o presidiendo una escena donde las armas y las herramientas cobran vida y capturan hombres. Los ornamentos, emblemas o vestimentas que identifican al sacerdote guerrero como el personaje que representaba a la cuarta deidad (D), es una corona o tocado en forma de "V", una túnica ritual con pequeñas placas cuadrangulares de cobre dorado, que en la parte posterior lleva una especie de cola con cascabeles:
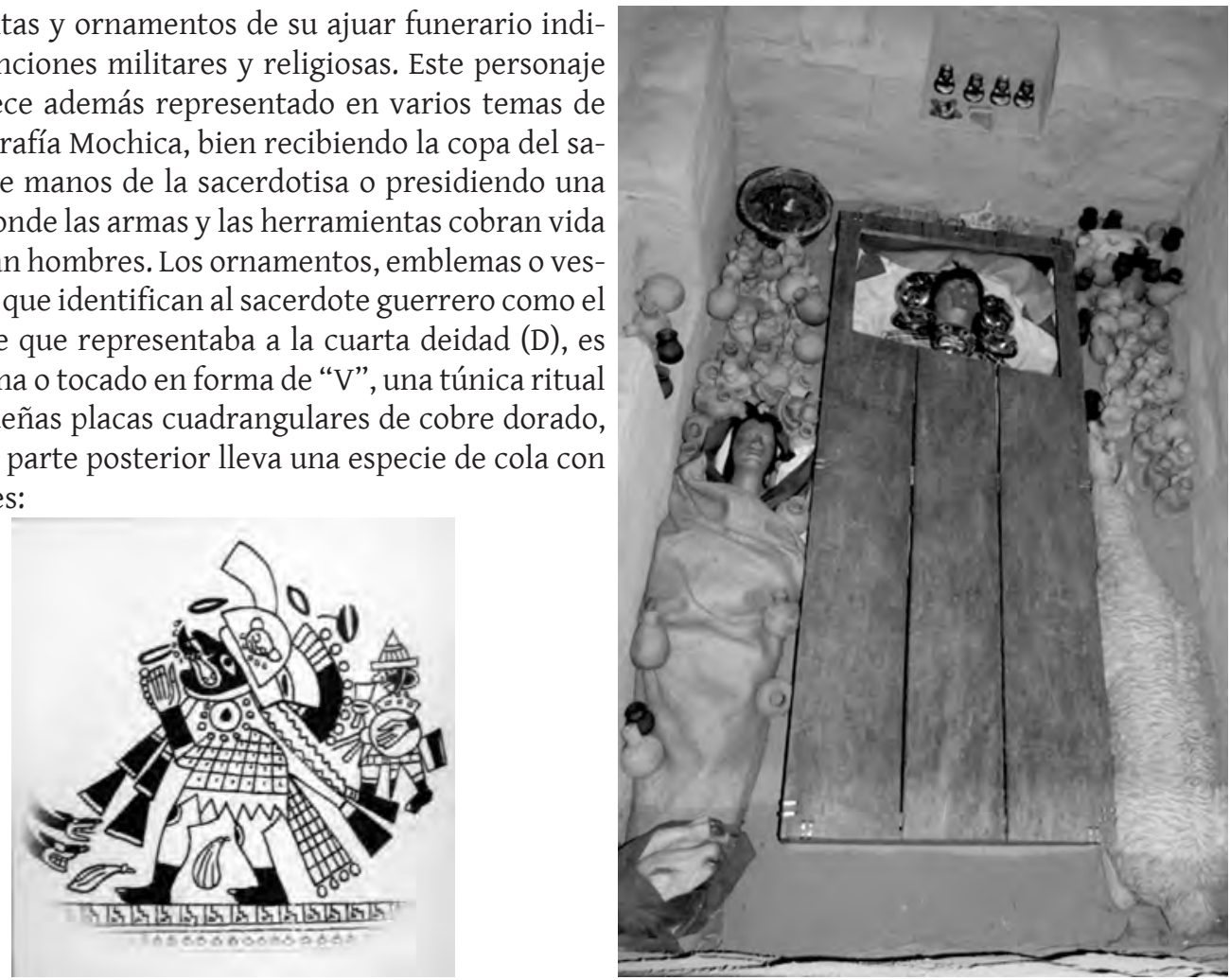

Imagen 3.- El personaje "D" de la "Presentación", al parecer fue descubierto finalmente en "Huaca Rajada" de Sipán, se trataría de un Sacerdote y Guerrero, pero que además habría tenido "funciones de músico" pues se halló una gran cantidad de artefactos sonoros e instrumentos musicales en su tumba.

8. Sin embargo, luego aparecerían algunas dudas sobre si es realmente o no el personaje (D) faltante: Luis Chero Zurita informa que el personaje descubierto en la tumba 14 reposaba en una tarima de madera y tenía en su tumba, entre otros elementos funerarios, coronas desarmadas "con dos alas tipo el personaje D", dos copas, corona con diademas y volutas, un plumero, unas porras con cabeza de metal, un idolillo de cobre fundido de unos 12 $\mathrm{cms}$. De alto y que podría ser una representación en miniatura del propio personaje enterrado. En la línea de este trabajo son dos los elementos que parecen destacar en este entierro: por un lado la aparición de dos copas de cobre dorado de $13 \mathrm{cms}$. De diámetro y una hermosa corona metálica de penachos de 47 centímetros de altura. Si las copas siempre han sido asociadas a la función básicamente ritual del personaje, si además este personaje tiene elementos del "hombre-búho" tan conocida de la iconografía moche entonces tenemos la base para afirmar que se trataría de otro gran sacerdote. Pero nos encontramos con que el gran sacerdote moche ya había sido descubierto e identificado con relativa claridad hace ya varios años. En esta misma tumba se ha encontrado elementos de uso militar por lo que se considera que también el personaje cumplía esas funciones y, para variar tenía un tocado en forma de V que asemeja mucho al tocado del personaje D entonces la pregunta es inevitable: ¿Quién es el nuevo personaje descubierto por Luis Chero Zurita? El debate se hace más complejo porque este personaje sería más antiguo que el Señor de Sipán en más o menos 60 años, lo que lo ubica, temporalmente hablando, entre el Viejo Señor de Sipán y el Señor de Sipán. Adicionalmente presenta también un rico ajuar funerario, elementos de mando y de rango y lo destacable es la existencia de dos copas que son elementos rituales de primer orden y que no las tenía el Señor de Sipán. La pregunta surge de manera inevitable: ¿se trata del personaje D que se está buscando 0 se trata de un nuevo Señor de Sipán que se agregaría a los tres ya reconocidos? La Tumba 14 nos pone sobre aviso de que para caracterizar con precisión a un personaje de la élite Moche se tiene que tener muchos más elementos. En este caso la existencia de la copa en la mano no basta pues parece que las funciones de estos personajes fueron cambiando con el tiempo, siguiendo una lógica que cuesta mucho desentrañar, justamente por la inexistencia de registros precisos y por la insuficiencia del instrumental analítico con el que contamos. Ver: http://arriero.galeon.com 
De seguro que debe haber pruebas suficientes que hacen pensar a Chero Zurita que finalmente había sido descubierto la tumba del personaje D de la ceremonia del "sacrificio" o "presentación". A nosotros nos llama poderosamente la atención el hecho de que este personaje fuera enviado al "mundo de los ancestros" (enterrado) con una gran cantidad de aparatos sonoros que indicarían que "también habría sido un gran músico" o "aficionado a la música" (o por otras "poderosas" razones), aunque cabe la posibilidad que estos sean sólo "ofrendas"; pero igual las interrogantes del ¿Por qué? Siguen intactas:

La cerámica registrada como ofrendas en la Tumba 14 suman un total de 204 piezas completas, divididas en dos grandes grupos: vasijas y otras formas. Sobre el primero, se reconocen sólo vasijas cerradas, de las cuales se ha identificado dos formas: cántaros (154 piezas) y botellas (5 piezas). Sobre la segunda, otras formas, se constituyen de cerámica en miniaturas que representan cántaros escultóricos antropomorfos (9 piezas), máscaras (10 piezas), instrumentos musicales de viento como trompetas con diseño zoomorfo (9 piezas), conus (10 piezas); así como también crisoles (5 piezas) y antaras (2 piezas) (Chero Zurita 2013). ${ }^{9}$

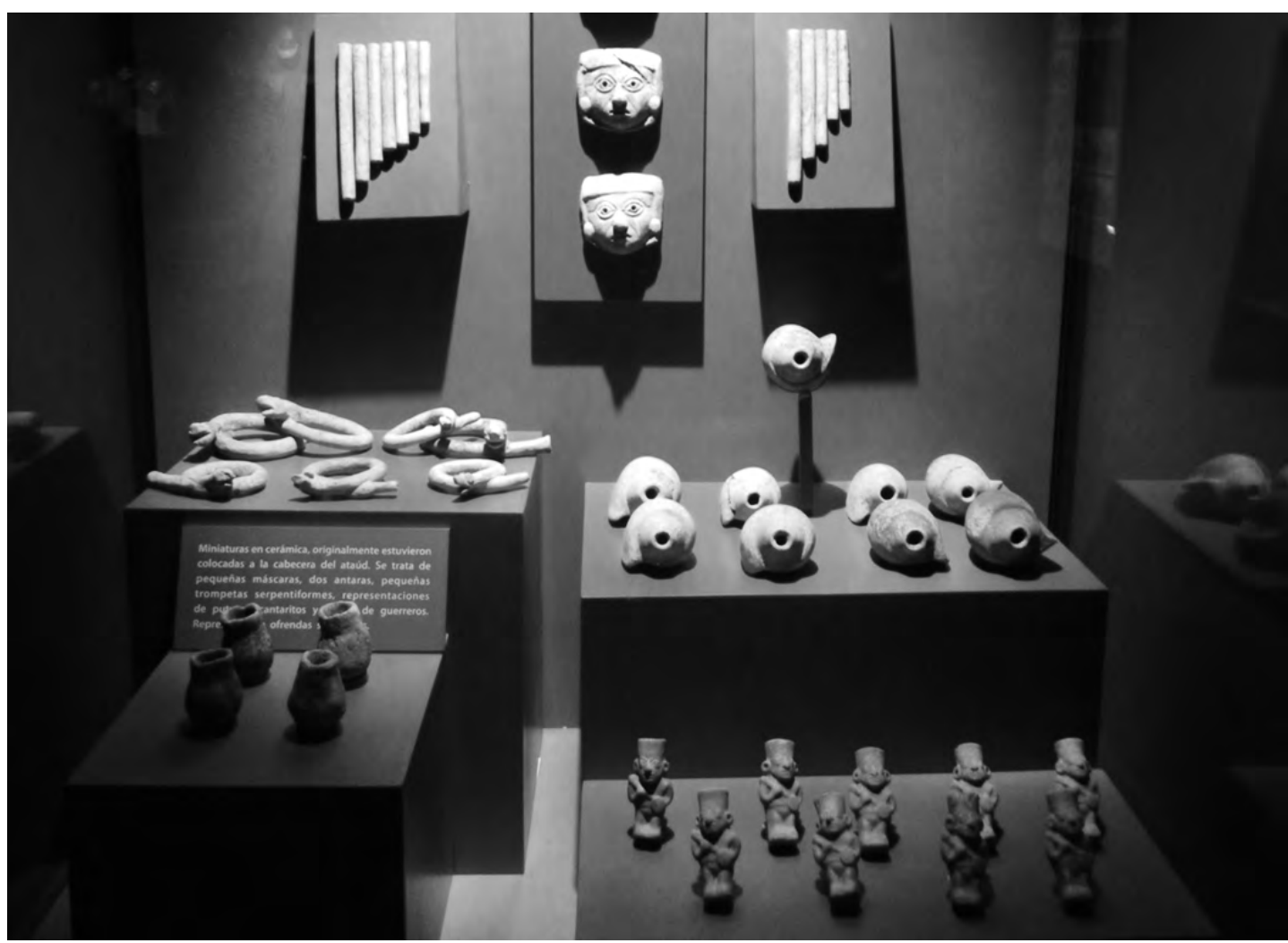

Imagen 4.- Exposición de piezas arqueológicas en el museo de sitio de Huaca Rajada: Miniaturas de artefactos sonoros (pututos y trompetas de cerámica) e instrumentos musicales (dos "antaras") encontrados en la tumba 14, tumba del "Sacerdote Guerrero de Sipán con probables funciones de músico".

9. El subrayado es énfasis nuestro debido a que será importante distinguir entre "ofrendas" y "pertenencias" en una tumba. 
Como observamos, se encontraron en esta tumba diecinueve artefactos sonoros: nueve (9) trompetas de cerámica "escultóricas" con representación de serpientes y que la arqueología supone que son "miniaturas", diez (10) piezas de "pututos" (conus) elaborados en cerámica e instrumentos musicales, dos piezas de flautas de pan o dos "antaras", aunque en algunas referencias del museo y del libro de Chero Zurita se habla de "una antara", punto que trataremos a continuación.

\section{LA FLAUTA DE PAN DEL “SACERDOTE GUERRERo"}

Como podemos observar en las imágenes 6 y 7, la "antara" o las "antaras" halladas son de cerámica, fueron hechos de tierra colorada (arcilla) y presenta una construcción o acabado "simple" o "rústico" o en todo caso el tiempo y el entierro le habrían afectado. Comparándolas con las "antaras" de la sociedad Nazca contemporáneo a ellos, extraña no apreciar una técnica avanzada en su confección toda vez que los Mochicas para esta época ya habían logrado una gran desarrollo del trabajo en cerámica $^{10}$. Estas "antaras" Mochicas poseen tubos cuyos largos externos oscilan entre $6 \mathrm{~cm}$ (los más chicos) hasta los $15 \mathrm{~cm}$ en promedio (los más largos) y cuya circunferencia externa es homogénea en su largo distal, es decir, no tiene discontinuidades o forma de "tubos complejos" como las "antaras" Paracas, tampoco embocaduras ojivales como las "antaras" Nazca (véase imágenes 5 y 6).

En la exposición, se distingue claramente que los tubos de estas "antaras" se encuentran "separados"; es decir, están sueltos y no presentan ataduras de sujeción, lo que quiere decir que estos se deben haber destruido en sus años de entierro. Entonces ¿Qué tipo de sujeción habrían tenido? ¿Hilos, cañas o la misma cerámica? Pensamos que debió estar fijado con una pasta del mismo material (arcilla) que en su tiempo habría funcionado muy bien, pero que con el paso del tiempo y el peso de la tierra se habrían difuminado. Sin embargo, esto requiere un exhaustivo análisis de la pieza in situ.

Por otro lado, observamos que no posee "resonadores", por lo menos aparentemente no, salvo que una de las hileras fuera el "resonador" del otro, en cuyo caso se trataría de una "flauta de pan de una sola hilera con resonador". Pero en el caso de tratarse de dos flautas de pan-como se muestra en la exposición-, estaríamos entonces ante una de "modelo siku", y posiblemente sería "dual complementario" (toda vez que no se trata de un solo tipo de flauta repetida o duplicada). Entonces urge una inspección profunda con acceso al archivo visual (video o fotográfico) del desentierro ${ }^{11}$.

\section{1) Flauta de pan ¿Dual o individual?}

Entre los arqueólogos y especialistas del Museo, no hay una claridad si se trata de "una antara" o de "dos antaras", para nuestro tema es crucial. En la exposición se observan "dos antaras" pero en la réplica del entierro del sacerdote-guerrero se exhibe "una zampoña", es decir como si se tratara de "un solo instrumento", vale decir las dos hileras juntas una sobre otra y atadas como en la actualidad se presenta y se toca una zampoña. En el libro de Luis Chero Zurita se habla de "dos piezas de antaras" (p. 101) pero en otra página del mismo libro se señala que se había hallado "una antara de cerámica" (p. 103). Asignarle un valor de unidad o de pluralidad es determinante en este caso, la diferenciación entre flautas de pan de "modelo antara", "modelo siku" y "modelo zampoña", es vital.

10. En general una interrogante ronda cuando se estudia las "antaras" en la sociedad Mochica respecto de las técnicas de su elaboración: 1) Por qué no se usaron masivamente la cerámica para fabricar las "antaras" si este uso era de conocimiento para otras esferas de la vida cotidiana. 2) El nivel alcanzado en el uso de la cerámica era de alta calidad, así lo indican una gran cantidad de vasijas y demás ¿Entonces porque no se usó la misma técnica para la construcción de estos instrumentos?

11. Una mayor información sobre los tipos de flautas de pan arqueológicas y etnográficas además de sus técnicas de interpretación y demás características, podemos encontrarlo en Sánchez 2013 op. cit. 


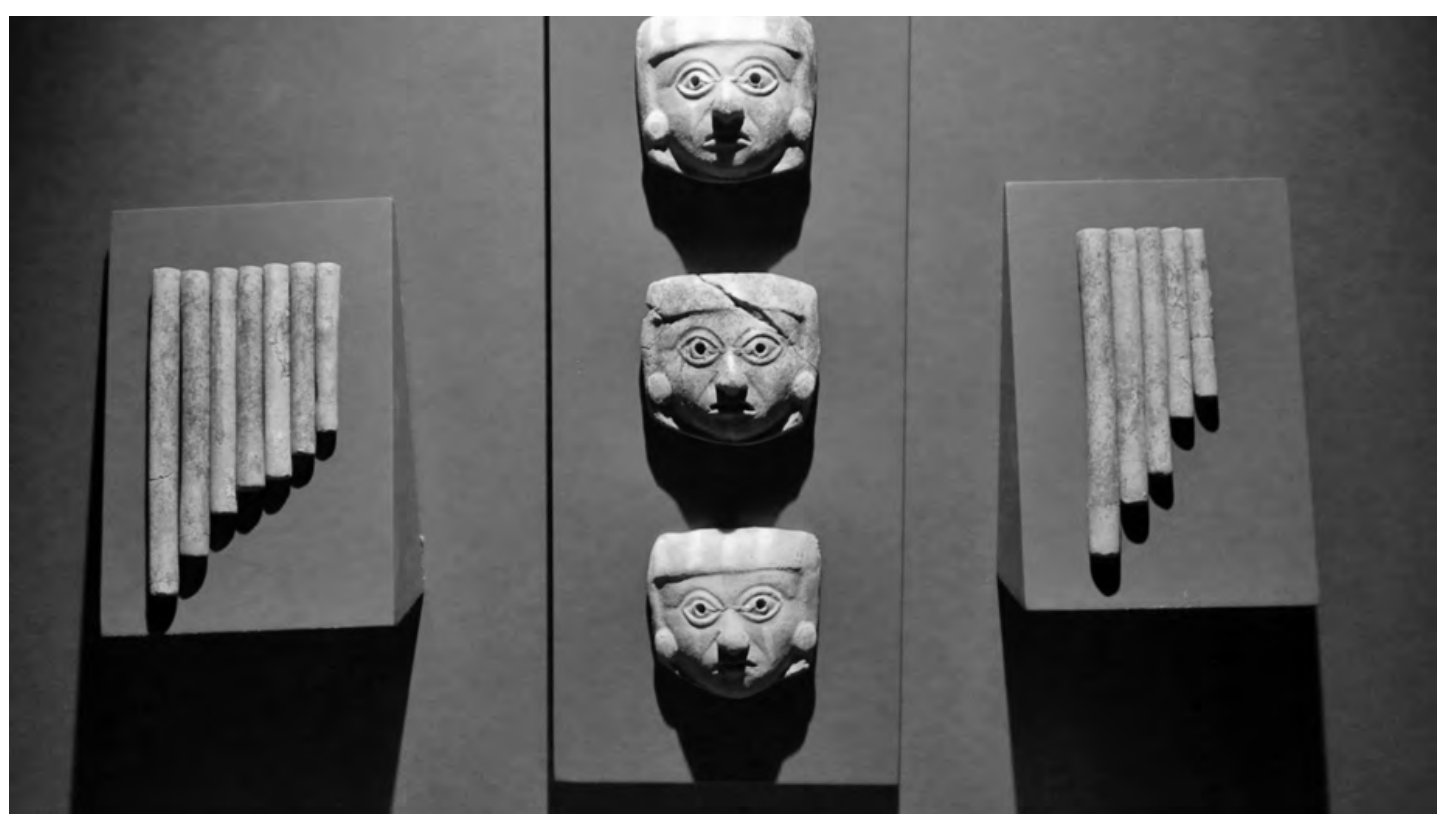

Imagen 5.- Flautas de pan encontradas en la tumba 14, tumba del Sacerdote - Guerrero quien además tendría también "funciones de músico". Exhibición del museo de sitio.

Los arqueólogos de Sipán, parecían tener la idea de que esta flauta de pan, al pertenecer a un "solo" personaje, era evidentemente un "solo" instrumento, es decir, un instrumento personal (específicamente de ejecución individual aunque este tuviera dos filas), posiblemente se piensa que la técnica de ejecución pudo haber sido el de la zampoña actual (flauta de pan de dos filas, una tras otra, conformando un solo instrumento para ser tocado también por un solo músico). Deducciones que por supuesto no son convincentes para nosotros que sabemos de las especificidades de las flautas de pan andinas: las flautas de dos filas de ejecución individual son necesariamente las que poseen "resonadores", la técnica de la zampoña no es prehispánico. Los arqueólogos a todas luces no tenían (creo que no tenían por qué tenerlo), presente las especificidades del instrumento.

Una de las preocupaciones más trascendentales trata sobre la dualidad de las flautas de pan del sacerdote guerrero. Para ello es necesario saber si estas habían sido encontradas separadas por hileras; suponemos que debió ser así, puesto que es la forma como se la presenta en el Museo, pero la duda nos asalta. Tal vez habrían sido encontrados todos los tubos de las "antaras" sueltos y agrupados en un mismo escenario; entonces ¿Cómo se sabría si eran dos hileras de tubos (de 5 y 7 tubos como se indica en la exposición museográfica) o de una sola hilera a manera de las flautas de 12 o más tubos como las actuales antaras norteñas? ${ }^{12}$

De tal manera que no descartamos ninguna posibilidad mientras no tengamos acceso a los archivos y un análisis acústico: Podría tratarse de una flauta de pan de 12 tubos (de uso individual) morfológicamente "una antara", por lo tanto de uso individual. Puede tratarse -difícilmente-, de una

12. Por esos días de trabajo exploratorio tuve la suerte de conversar con el arqueólogo Walter Alva, quien también le llamaba "el músico" (¿Quién habría sido el otro músico si el instrumento se tocaba entre dos?). También se comprometió hacerme llegar fotos originales del desentierro del "Sacerdote Guerrero de Sipan" en el que se podía ver más detalles del descubrimiento, datos obviamente necesarios para una mayor y profunda investigación. 


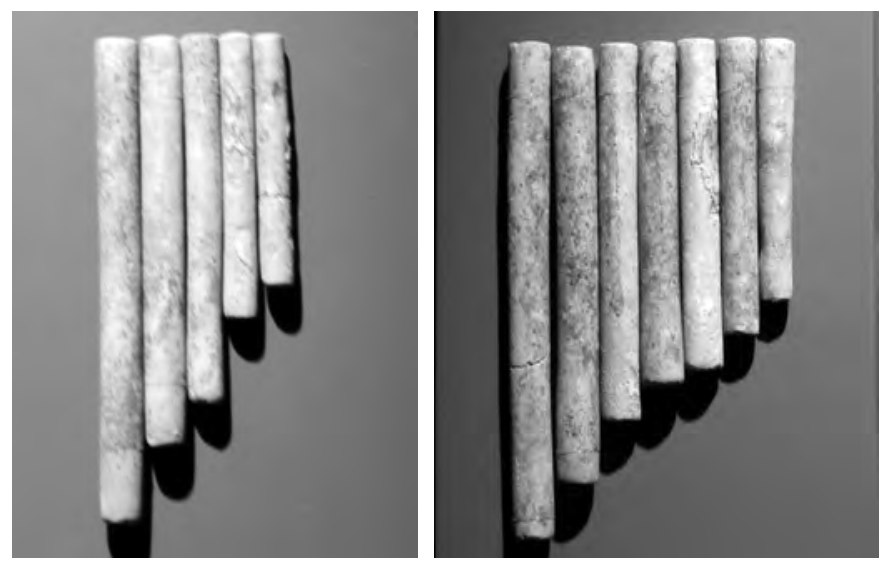

Imagen 6.- Flauta de pan del Sacerdote Guerrero y probable músico. Se distingue que los tubos se encuentran "sueltos", ¿Lo habría tocado solo? ¿Habrían sido efectivamente de dos hileras? ¿Qué significa, o por qué la simplicidad de su aspecto? ¿Quiénes habrían sido sus constructores? sola flauta de pan pero de dos hileras (de 6x6, o de 7x5) morfológicamente "una zampoña" y por lo tanto también de uso individual. Podría tratarse de una sola flauta de pan "con resonador" entonces también de uso individual. También podría tratarse de la muy "iconografiada" flauta de pan dual o "bipolar" (de 7x5 tubos como señala la exposición).

Ciertamente, por la gran cantidad de iconografías, podemos conjeturar que la sociedad Mochica conoció (o inventó) el "diálogo musical complementario o interdependiente" en las flautas de pan (al mismo estilo de los actuales sikus altiplánicos, imágenes 7a y 9a ${ }^{13}$. ¿Esta sería una de ellas? Y si así habría sido sería interesante saber ¿Con qué otro músico dialogaba musicalmente? Pero tampoco las flautas de pan individuales fueron ajenas a esta sociedad y el llamado "sacerdote guerrero con funciones de músico" pudo haber sido uno de estos pues muchísimas cerámicas reflejan el uso solista o unitario de este instrumento al mismo modo de los actuales antaristas del norte peruano (imagen $7 \mathrm{~b}$ ).

\section{2) La flauta de pan de un Sacer- dote Guerrero}

Pensamos a priori que la música de las flautas de pan en el pasado prehispánico habría estado ligado casi exclusivamente a rituales religiosos, especialmente a los entierros, a la muerte, al pasaje hacia el mundo de los ancestros, etc. Luego la pensamos como parte del ocio y el disfrute de una fiesta donde se conjugaría con el baile y la danza. Claro que razones no faltan pues muchas de estas han sido halladas en entierros de personajes principales, poseen rasgos cadavéricos (más aun en el caso Mochica) y recién al final de los tiempos prehispánicos los cronistas evidenciaron su participación en las

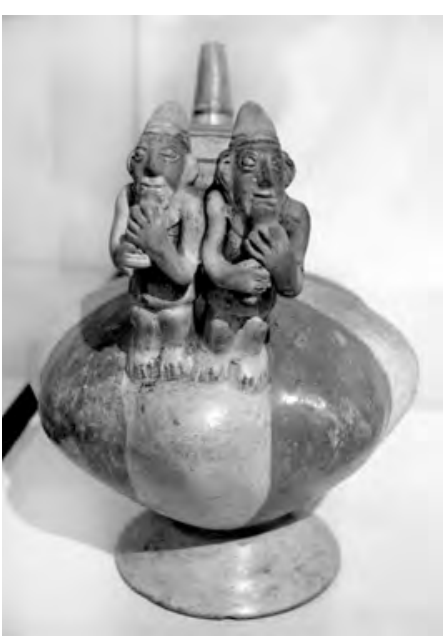

Imagen: 7a.- Vestigios que prueban la existencia de flautas de pan Mochica de uso dual (no necesariamente interdependiente). 7b.- Flauta de pan y músico individual o solista. fiestas populares.

13. Los esposos d'Harcourt, Isabel Aretz y Américo Valencia señalan que en los Mochicas se percibe el "diálogo musical" (peculiar técnica de ejecución musical que vemos en los sikuris altiplánicos actuales), pues así lo evidenciarían varias representaciones iconográficas en las que se puede distinguir a dos personajes ejecutando una flauta de Pan cada una y atada con una cuerda que señalaría claramente esta característica. 
Ahora que tenemos un caso fehaciente de conjunción entre la flauta de pan y un jefe guerrero, tendríamos que considerar otros roles y funciones de este instrumento (ahora dentro de la elite Mochica), donde tipos de música, sonoridad y percepción misma del instrumento se conjugaran en otra dimensión. Es posible que la flauta de pan haya sido parte de un emblema o motivo de guerra, un artefacto sonoro interviniente en las peleas rituales, en los combates, en los sacrificios y en el enfrentamiento a la muerte. A esta idea se sumaría la existencia de los "pututos" y cornetas encontradas y que son artefactos sonoros que por esos tiempos y lugares eran mayormente utilizados en contextos bélicos y rituales de sacrificios (Cupisnique, Sechín, Chavín), debido al carácter sonoro que poseen. Entonces ¿Qué relación tendrían estos artefactos e instrumentos con el jefe guerrero, un sacrificador? ¿Sería un músico, o se trata de un simbolismo? Difícil suponer que este hacía además funciones de músico, y más aun de músico festivo, tal vez, la flauta de pan no era en si un instrumento musical, sino estrictamente hablando un "artefacto sonoro" pensado en darle vida a los contextos de carácter bélico y rituales de sangre y muerte. Vale decir que la flauta de pan habría acompañado los combates rituales, los ajusticiamientos de los rivales perdedores y las ceremonias sangrientas como el indicado en el tema de la "Presentación" o "Sacrificio".

\section{3) La flauta de pan en la élite Mochica}

Por lo visto, las flautas de pan estaban muy presentes en los sectores de las más altas jerarquías Mochicas (imagen 8), las iconografías y demás restos nos señalan su evidente presencia en ceremonias de personajes de gran importancia. Muy por el contrario podemos decir que casi no la encontramos relacionado al pueblo de acuerdo a lo que nos deja la ciencia arqueológica, sino como pertenencias $u$ ofrendas para personajes de importancia. ${ }^{14}$

Sin embargo, nos llama poderosamente la atención la construcción "aparentemente rústica" de esta pieza, frente, por ejemplo a lo que la sociedad Nazca había logrado por esos tiempos. Nos sorprende más aún cuando en el estadio intermedio o de apogeo, el uso de la cerámica era realmente muy superior en la sociedad Mochica ¿Por qué entonces una flauta de pan de cerámica construida para el uso de un personaje de alto rango o para ofrecerle a él (si fuera el caso) no fue realizada con la técnica sofisticada? También llama la atención que en iconografías donde aparecen personajes de importancia portan o ejecutan estas flautas de pan (imagen 9), se las ve con detalles esplendorosos (cabezas de animales, detalles fastuosos, etc.), pero en este caso la encontramos "rústica y simple" ¿Fue acaso construida así o se ha deteriorado con el paso del tiempo?

Por otro lado, todo lo referente a la construcción de estos instrumentos es otro tema que tendremos que considerar ¿Quiénes lo habrían fabricado? ¿Por qué no se percibe un desarrollo masivo y mayor técnica? ¿Eran especialistas o todo lo contario? Es posible que esto pueda resolver el porqué de esta aparente simplicidad o rusticidad de la flauta de pan del sacerdote guerrero.

También queda en cuestión el hecho de que cuando los especialistas (como Valencia, Bolaños y otros) señalan que las flautas de pan mochicas habrían sido construidos en "cañas", material perecible que justamente explicaría que no hayan sobrevivido hasta la actualidad; aparece nuevamente la interrogante: siendo la cerámica (y los metales preciosos) el material más preciso para elaborar piezas de importancia ¿Por qué no se usó la cerámica para la elaboración de este instrumento, más aún si esta iba pertenecer o ser ofrenda para un gran jefe?

14. Pero también tengamos en cuenta que una crítica es que la arqueología prehispánica andina, es una arqueología de la élites, pues la mayoría de los restos arqueológicos que tenemos y estudiamos provienen de estos sectores, lo que no quiere decir que el pueblo no haya practicado similares rituales y demás actos sociales, más aún en el mundo de la música. 


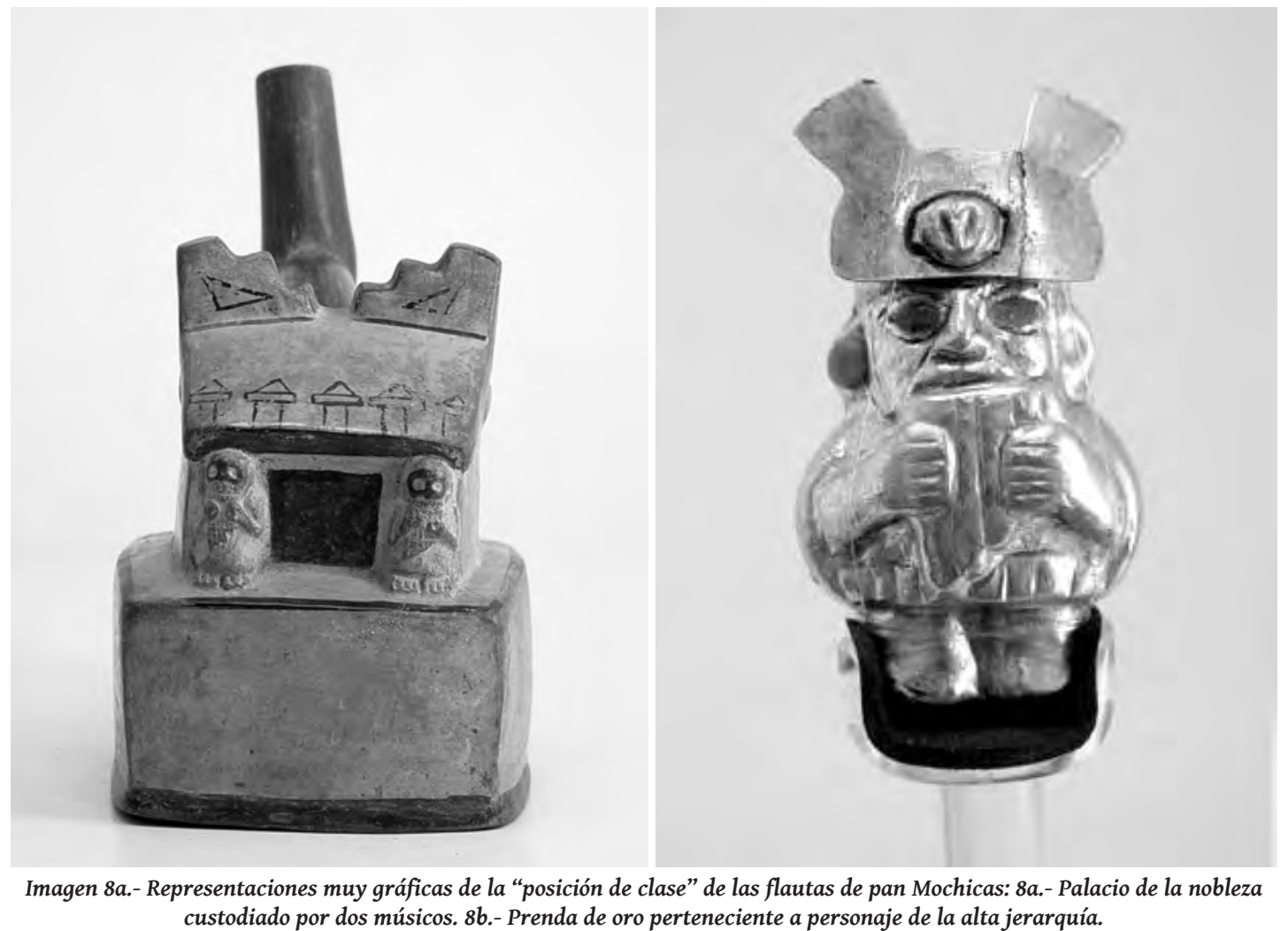

\section{4) La flauta de pan Mochica: ¿"Prenda" u "ofrenda"?}

No deberíamos descartar, toda vez que estamos en la etapa de elaboración de hipótesis de trabajo, la posibilidad que los artefactos sonoros e instrumentos musicales hallados en este entierro, sean estrictamente "ofrendas".

Esta idea se puede reforzar por la catalogación de "miniaturas" y "ofrendas" que le hace el Museo de sitio y el libro de Luis Chero Zurita donde se lee: "Miniaturas constituido por piezas de dimensiones menores... como máscaras, trompetas, conus y antara de cerámica." (p.102, 103). En otros pasajes del mismo, se les considera también "ofrendas" (lo que no elimina que sea también de pertenencia del enterrado): "La cerámica registrada como ofrendas en la Tumba 14..." (p. 101). En todo caso los conceptos de "miniaturas" y "ofrendas" nos llaman poderosamente la atención y debe ser motivo también de investigación. ${ }^{15}$

Sin embargo, teniendo en cuenta algunas iconografías Mochicas podemos deducir que ciertamente la flauta de pan fue de uso (y de pertenencia) de personajes de alta jerarquía Mochica, pues se puede ver a estos tocando estas flautas de pan y en dúo (imagen 10). Sin embargo, nuevamente nos asalta otra interrogante: ¿Por qué estas flautas de pan tan exuberantes o espléndidamente graficadas, no se han encontrado? La flauta de pan encontrada en la tumba 14 no parece ser la misma que nos

15. Énfasis de subrayado nuestro. 

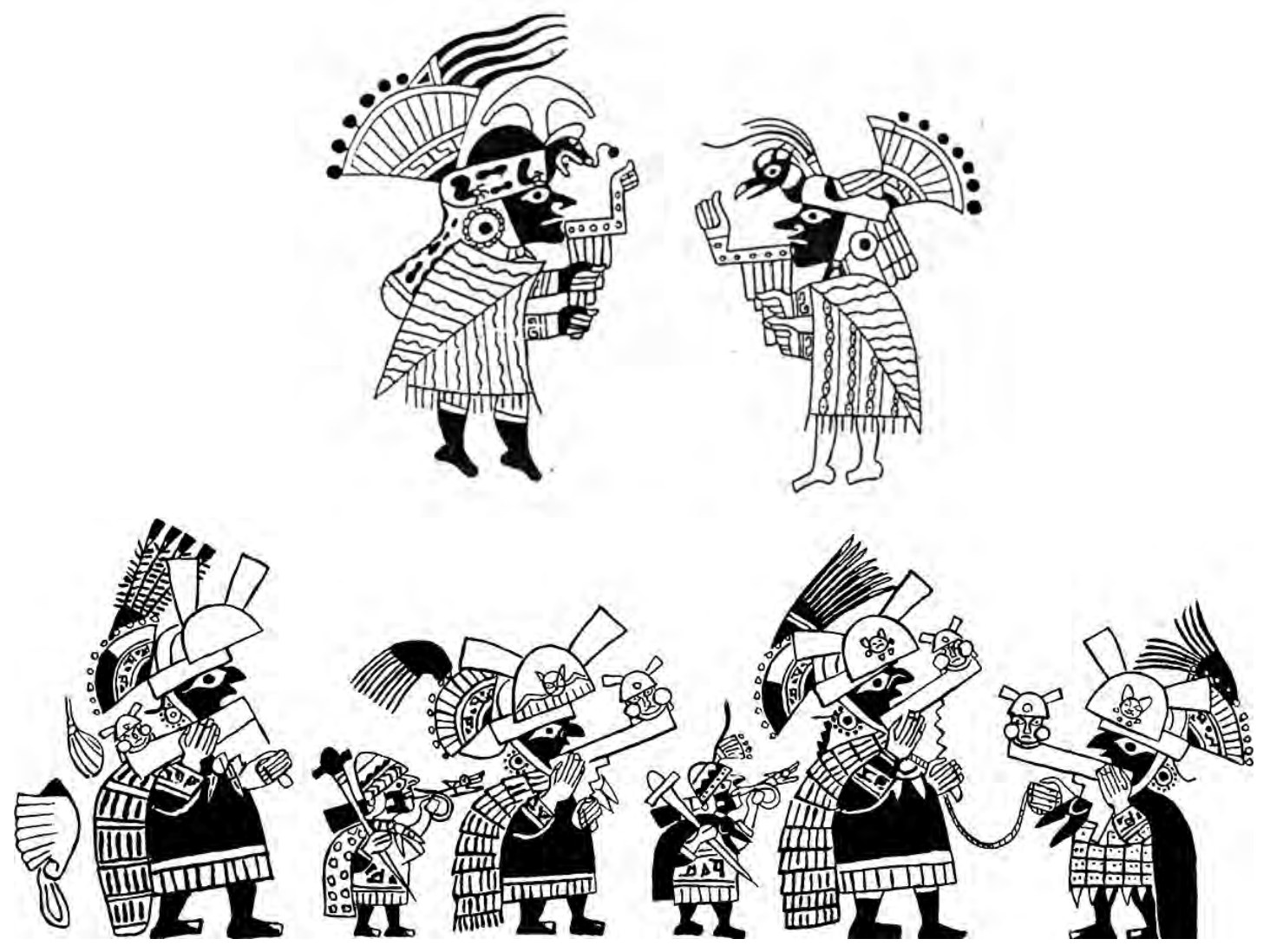

Imagen 9.- Representaciones gráficas que evidenciarían la "posición de clase" de las flautas de pan y su posible real ejecución por estos personajes de alta jerarquía. Daniela La Chioma (2014) sostiene que además el último personaje de la derecha de esta segunda imagen sería el "Sacerdote Guerrero" por los parecidos de las indumentarias.

muestran las iconografías ¿No estaríamos nuevamente ante elementos imaginarios-simbólicos? Por lo tanto ¿La flauta de pan del sacerdote guerrero Mochica de la tumba 14, no sería una ofrenda como las demás miniaturas?

\section{CONCLUSIONES}

Percibimos una errada idea en los arqueólogos de la zona que a priori parecen sostener que la flauta de pan hallada en la tumba 14, del sacerdote guerrero de Sipán, sería un instrumento de "modelo zampoña", es decir como si el instrumento hubiera sido de dos filas de tubos constituyendo un solo instrumento para un solo instrumentista, es decir como las actuales zampoñas. Así también la consideran en la réplica de la tumba 14.

No cabe duda de que la sociedad Mochica tuvo como principal instrumento musical a la flauta de Pan y debió este haber participado en diversos momentos de la vida social, en el mundo de los vivos como en el de los muertos, en las élites gobernantes como en el pueblo; en la guerra, en los ritos religiosos y en la fiesta pública, así lo indican las iconografías y cerámicas encontrados. Pero la casi inexistencia de restos arqueológicos de este tipo de flautas, ha dificultado avanzar más allá de las suposiciones, por lo que esta flauta de pan puede entregarnos muchas nuevas pistas. 
Hasta ahora esta flauta de pan, nos genera más dudas e interrogantes que certidumbres, la principal es saber si se tratan de flautas de pan duales y si esta dualidad es complementaria o de interdependencia. Los Mochicas con los restos iconográficos y representaciones en las cerámicas, nos testimonian que posiblemente hayan conocido las flautas de pan individuales (modelos "antaras"), pero además no cabe duda que se trata de la primera sociedad pre hispánica que muestra con claridad el conocimiento de las flautas de Pan denominadas interdependientes, duales o complementarias (modelos "sikus"). Américo Valencia es quien más ha insistido que la sociedad Mochica ya conocía y usaba las flautas de pan duales (al que denomina "bipolares"). Sin embargo, César Bolaños afirma que si bien es posible que los Moches pueden haber conocido las flautas de pan duales, no quiere decir que necesariamente hayan sido estas interdependientes o dialogadas, pudieron haber sido ejecutadas al unísono por ejemplo.

En nuestro caso estamos a la espera de poder tener acceso a las flautas de pan exhibidas y custodiadas en el Museo de Sitio de Huaca Rajada en Sipán (Lambayeque) y sobre todo a los archivos de estos hallazgos.

\section{BiBLIOGRAFÍA}

CASTILLO B. Luis

2000 La ceremonia del sacrificio - batalla y muerte en el arte Mochica. Museo Arqueológico Rafael Largo Herrera. Lima.

2000 Los rituales Mochicas de la muerte. Los dioses del antiguo Perú Museo MAKOWSKI, K (Editor). Banco de Crédito del Perú.

CHERO ZURITA, Luis

2013 Huaca Rajada / Sipan: Esplendor y complejidad. S/ref.

GOLTE, Jurguen

2009 Moche, Cosmología y Sociedad: Una interpretación iconográfica. Instituto de Estudios Peruanos.

HOCQUENGHEM, Anne María.

1987 Iconografía Mochica. PUCP

LA CHIOMA S. Daniela

2014 La representaciones iconográficas de músicos en la cerámica del periodo Moche Medio: un debate sobre instrumentos sonoros y roles sociales protagónicos. Ponencia. En: https:// www.academia.edu

\section{MAKOWSKI, Krzysztof}

2000 Las divinidades en la iconografía Mochica (eds.). Los dioses del antiguo Perú. Lima, Banco de Crédito del Perú.

SÁNCHEZ H., Carlos

2013 La flauta de pan andina: los conjuntos de sikuris metropolitanos, urbanos o limeños. UNMSM Fondo Editorial, Lima 2013. 
